\title{
Warming Increases the Carbon Sequestration Capacity of Picea schrenkiana in the Tianshan Mountains, China
}

\author{
Honghua Zhou (D, Yaning Chen, Chenggang Zhu, Yapeng Chen *, Yuhai Yang, Weihong Li and Shifeng Chen \\ State Key Laboratory of Desert and Oasis Ecology, Xinjiang Institute of Ecology and Geography, \\ Chinese Academy of Sciences, Urumqi 830011, China; zhouhh@ms.xjb.ac.cn (H.Z.); chenyn@ms.xjb.ac.cn (Y.C.); \\ zhuchg@ms.xjb.ac.cn (C.Z.); yangyh@ms.xjb.ac.cn (Y.Y.); liwh@ms.xjb.ac.cn (W.L.); \\ ChenShifeng_GS@163.com (S.C.) \\ * Correspondence: chenyp@ms.xjb.ac.cn; Tel.: +86-135-7940-8356
}

check for

updates

Citation: Zhou, H.; Chen, Y.; Zhu, C.; Chen, Y.; Yang, Y.; Li, W.; Chen, S. Warming Increases the Carbon Sequestration Capacity of Picea schrenkiana in the Tianshan Mountains, China. Forests 2021, 12, 1066. https://doi.org/10.3390/ f12081066

Academic Editors: Shirong Liu, Wenhua Xiang and Scott X. Chang

Received: 3 June 2021

Accepted: 6 August 2021

Published: 10 August 2021

Publisher's Note: MDPI stays neutral with regard to jurisdictional claims in published maps and institutional affiliations.

Copyright: (c) 2021 by the authors. Licensee MDPI, Basel, Switzerland. This article is an open access article distributed under the terms and conditions of the Creative Commons Attribution (CC BY) license (https:/ / creativecommons.org/licenses/by/ $4.0 /)$.

\begin{abstract}
As an essential part of terrestrial ecosystems, convenient and accurate reconstruction of the past carbon sequestration capacity of forests is critical to assess future trends of aboveground carbon storage and ecosystem carbon cycles. In addition, the relationship between climate change and carbon sequestration of forests has been vigorously debated. In this study, dynamic change of carbon sequestration capacity in aboveground biomass of Picea schrenkiana (hereinafter abbreviated as P. schrenkiana) in the Tianshan Mountains, northwestern China, from 1850-2017, were reconstructed using dendrochronology. The main climate drivers that affected carbon sequestration capacity in aboveground biomass of $P$. schrenkiana were then investigated. The results showed that: (1) tree-ring width and diameter at breast height (DBH) of P. schrenkiana obtained from different altitudes and ages were an effective and convenient estimation index for reconstructing the carbon sequestration capacity of $P$. schrenkiana. The carbon storage of P. schrenkiana forest in 2016 in the Tianshan Mountains was $50.08 \mathrm{Tg} \mathrm{C}$ calculated using tree-ring width and $\mathrm{DBH}$, which was very close to the value determined by direct field investigation data. (2) The annual carbon sequestration potential capacity of $P$. schrenkiana exhibited an increasing trend from 1850-2017. Temperature, especially minimum temperature, constituted the key climatic driver resulting in increased carbon sequestration capacity. The contribution rates of temperature and minimum temperature to the change of $P$. schrenkiana carbon sequestration capacity was $75 \%$ and $44 \%$, respectively. (3) The significant increase of winter temperature and minimum temperature led to warming in the Tianshan Mountains, resulting in a significant increase in carbon sequestration capacity of $P$. schrenkiana. The results indicate that, with the continuous increase of winter temperature and minimum temperature, carbon sequestration of P. schrenkiana in the Tianshan Mountains is predicted to increase markedly in the future. The findings of this study provide a useful basis to evaluate future aboveground carbon storage and carbon cycles in mountain systems possessed similar characteristics of the Tianshan Mountains.
\end{abstract}

Keywords: tree rings; carbon sequestration; classification and regression tree; climate change; dendrochronology

\section{Introduction}

Forests are a crucial part of terrestrial ecosystems, and changes in their carbon storage play an important role in estimating the global carbon cycle. Indeed, forests store $45 \%$ of terrestrial ecosystems' carbon globally [1,2]. From 2006-2015, forests absorbed more than $25 \%$ of global carbon emissions, while deforestation and forest degradation comprised $10 \%$ of global carbon emissions [3]. Carbon sequestration of forests is demonstrated to be an essential ecosystem function to compensate for carbon dioxide emissions into the atmosphere due to human activities [4-6]. As a consequence, estimation of the carbon sequestration potential capacity of forests has become one of the main foci of global carbon cycle changes under future climate change. 
As the estimation basis of forest carbon storage and the global carbon cycle, carbon sequestration potential capacity in aboveground biomass of forests not only provides corresponding parameters for climate models, but also constitutes an important basis for the study of climate change uncertainty. Generally, increasing carbon sequestration potential capacity of forest aboveground biomass is conducive to reduce the concentration of carbon dioxide in the atmosphere, and thus alleviate the trend of global warming. Carbon sequestration potential capacity of forest aboveground biomass, however, may be also significantly affected by global climate change [7-9], since increasing global temperatures might stimulate decomposition of soil organic matter to enhance biomass production and carbon sequestration in forests [10-12]. In fact, the relationship between climate change and carbon sequestration of forest aboveground biomass has been a controversial topic. Certain extant literature proved that warming would improve biomass productivity by up to $100 \%$ in northern temperate hardwood and boreal forests [13-15]. In contrast, numerous investigations demonstrated that the effects of climate change that drove carbon sequestration dynamic changes in aboveground biomass of forests were highly variable over species and regions $[1,16,17]$. Lim et al. reported that the increase in production due to warming was transient (less than 10 years), and suggested that long-term warming (i.e., two decades) did not significantly affect aboveground biomass production and carbon sequestration in boreal Picea abies forest [18]. Such conflicting findings emphasize the urgent need to elucidate the relationship between climate change and long-term (i.e., more than two decades) carbon sequestration in aboveground biomass of forests.

To assess the relationship between climate change and forest aboveground carbon sequestration, it is essential to estimate the long-term continuous carbon sequestration potential capacity in aboveground biomass of forests. However, long-term and continuous dynamic change sequences of carbon sequestration in aboveground biomass of forests are challenging to obtain due to laborious and expensive field data or relatively short-term remote-sensing interpretation data. In order to overcome these challenges, studies suggested that annual carbon sequestration potential capacity in aboveground biomass of forests and its historical change could be calculated by measuring trunk diameter growth in trees over time or reconstructed by analyzing patterns in tree-ring growth (dendrochronology) [19-21]. This solves the short-comings of both labor-intensive and expensive forest resource inventory and unavailable satellite images prior to the 1970s in remote sensing. Indeed, it constitutes an effective method for estimating carbon sequestration potential capacity of forest biomass, as well as analyzing the relationship between long-term carbon sequestration potential capacity in aboveground biomass of forests and climate change.

The Tianshan Mountains is one of the seven major global mountain systems as well as the largest mountain system in an arid area in the world. The Picea schrenkiana (hereinafter abbreviated as P. schrenkiana) forest is currently the most dominant and widespread boreal forest in the Tianshan Mountains. It is also one of the most important zonal forms of vegetation in the Tianshan Mountains in northwestern China, and represents $60.8 \%$ of timber-growing stock and $54.0 \%$ of forest land in Xinjiang Province, China [22]. Changes of carbon sequestration potential capacity in P. schrenkiana forest play a critical role in carbon storage and the carbon cycle in the Tianshan Mountains. Abundant literature has investigated the static geographical patterns, biomass, NPP [22-26], and carbon sequestration [27-30] of P. schrenkiana forest in the Tianshan Mountains, although over a relatively short time period. To date, however, few studies have analyzed dynamic changes of carbon sequestration potential capacity in aboveground biomass of $P$. schrenkiana forest in more than five decades in the Tianshan Mountains. In particular, there is a paucity of research on the impact of long-term global climate change on forest carbon sequestration potential capacity in aboveground biomass of $P$. schrenkiana forest in the Tianshan Mountains.

In this study, we reconstructed the dynamic changes of carbon sequestration potential capacity in aboveground biomass of $P$. schrenkiana occurring over more than 100 years in the Tianshan Mountains, northwestern China, using dendrochronology, and analyzed corresponding effects of long-term climate changes on forest carbon sequestration potential. 
Based on our findings, we discuss the possible trends of carbon sequestration potential in aboveground biomass of P. schrenkiana in the Tianshan Mountains under future climate change. The results will be beneficial to predict and evaluate future change trends in carbon storage and carbon cycles of forest ecosystems in the Tianshan Mountains, as well as in mountain systems with similar characteristics.

\section{Materials and Methods}

\subsection{Study Area}

The Tianshan Mountains, located in the hinterland of Eurasia, belong to an extensive system of mountain ranges in Central Asia. It spans China, Kazakhstan, Kyrgyzstan, and Uzbekistan from east to west. The Tianshan Mountains is the largest independent latitudinal mountain system in the world, and are also the farthest mountain system from oceans and the largest mountain system in an arid area globally. Due to these characteristics, the Tianshan Mountains was designated as a World Natural Heritage Site in 2013. The Tianshan Mountains also constitutes a sensitive indicator of the potential impacts of global climate change due to its complex topography and unique natural conditions [31,32]. In this area, the average annual frost-free period is 136-154 $\mathrm{d}$, and the mean relative humidity is $50-60 \%$. Moreover, each year, there is approximately 5 months of typically lasting snow at $1800-3000 \mathrm{~m}$ (a.s.1.) of the mountains [33].

The P. schrenkiana forest is the most important forest type in the Tianshan Mountains. It could well be regarded as a wet island in arid areas. It is also the area with the highest biomass and richest species diversity in the Tianshan Mountains, which plays a central role in the water cycle and carbon sink/source in the Tianshan Mountains. The P. schrenkiana forest is also one of the largest and most important forests in Xinjiang, and comprises 54.0\% of its forest area, and $60.8 \%$ of timber volume and growing stock [32]. For these reasons, changes of carbon sequestration potential in aboveground biomass of $P$. schrenkiana forest are directly related to changes of carbon storage and the carbon cycle in northwestern China [29].

The study area is part of the southern Tianshan Mountains in northwestern China, located in the Tomur Peak National Natural Reservation (E 79 $50^{\prime} \sim 80^{\circ} 54^{\prime}, \mathrm{N} 41^{\circ} 40^{\prime} \sim 42^{\circ} 04^{\prime}$ ). The P. schrenkiana forest in the Tomur Peak National Natural Reservation is one of the most well-conserved spruce forests in the Tianshan Mountains [34]. P. schrenkiana forest in this area is relatively undisturbed by anthropogenic factors, tends to be markedly homogeneous, and is mainly concentrated between 1500 and $3000 \mathrm{~m}$ (a.s.1.), where optimum humidity and temperature exist [22].

\subsection{Tree-Ring Samples and Climate Change Data Collection}

P. schrenkiana tree-ring samples were collected from the Tomur Peak National Natural Reservation. Considering that age might affect tree growth, and further influence tree rings, biomass and carbon sequestration of trees, as well as considering that the age structure of forests is typically dissimilar along different altitudinal gradients [24,35], four $10 \mathrm{~m}$ (width) sample plots were set (Figure 1). The length of sample plots ranged the elevations from 1800 to $2800 \mathrm{~m}$ (a.s.1.). The range of sampled elevation was relatively broad to ensure that sufficient cores with different ages were obtained. The average canopy coverage was approximately $25-50 \%$. The trees grew in relatively sparse or isolated conditions, with minimum human disturbances at the sample sites. The following four age classes of trees were established according to diameter at breast height (DBH) in each sampling plot: $\mathrm{DBH} \leq 30 \mathrm{~cm}, 30<\mathrm{DBH} \leq 50 \mathrm{~cm}, 50<\mathrm{DBH} \leq 80 \mathrm{~cm}$, and $\mathrm{DBH}>80 \mathrm{~cm}$. $\mathrm{DBH}$ was calculated based on the circumference determined by a measuring tape. As our research aim was to identify historically dynamic changes of carbon sequestration in aboveground biomass and its climatic drivers, the growth of trees in different ages needed to be considered. In order to avoid the "big-tree selection bias" [36], a randomized dendrochronological sampling design was used. In each plot, one tree was selected every 20 trees, which could include all diameter classes of the population (including both young 
and old individuals) and avoided errors resultant from using a single tree age. Although the random sampling cannot completely eliminate the bias associated with slow-growing survivors, it can truly reflect the spatial distribution of forest stands of different ages as much as possible.

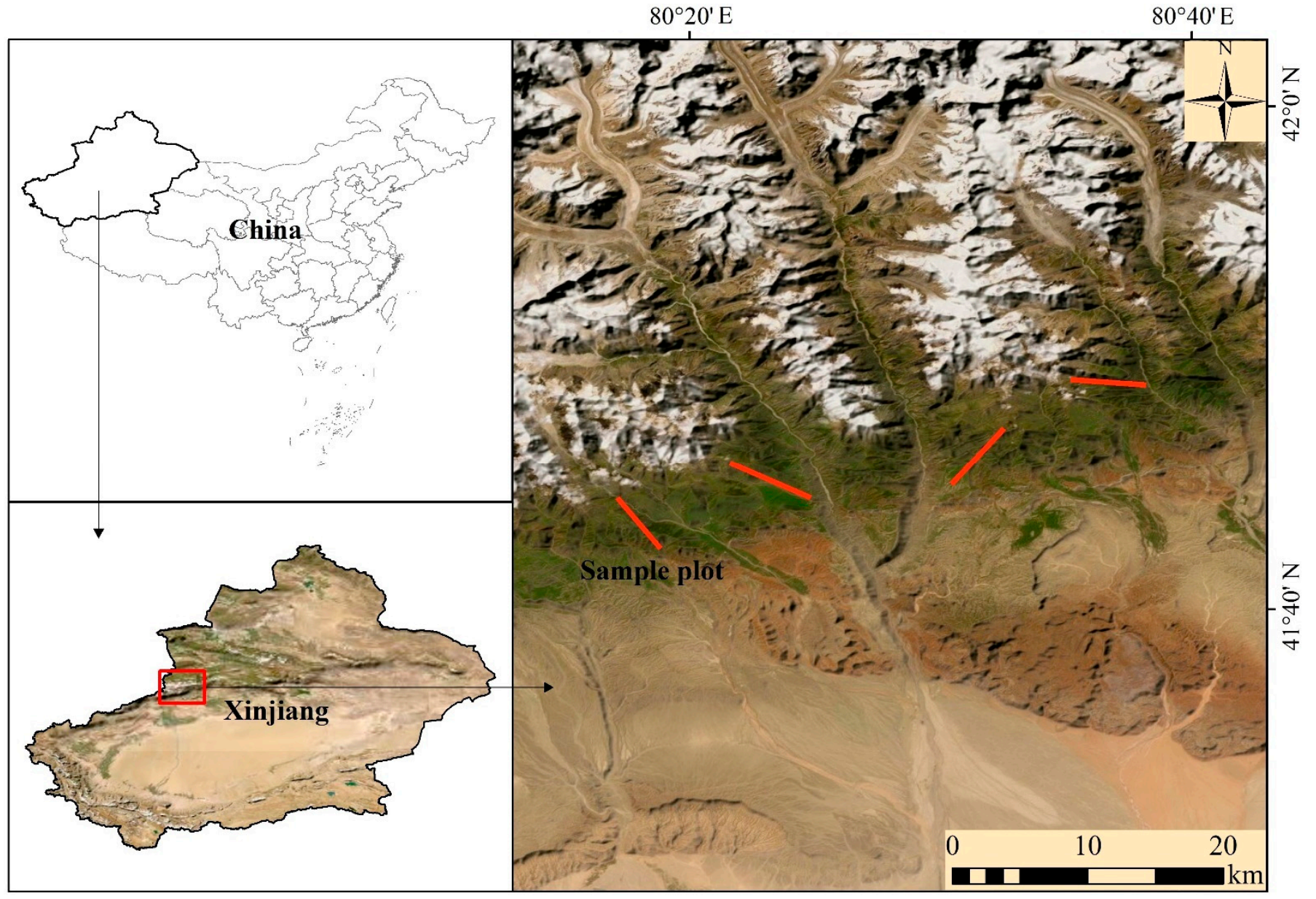

Figure 1. Sketch map of the study area.

Cores were taken in April 2018 at breast height, and two cores were collected from each tree to facilitate cross-dating by using an increment borer (Haglof Inc., Långsele, Sweden) $10 \mathrm{~mm}$ in diameter. In total, 468 cores from 234 trees were extracted from the sample sites.

In addition, a series of climate parameters, including precipitation, temperature, wind velocity, sunshine duration and relative humidity, were selected to analyze relationships between climate variables and carbon sequestration capacity of P. schrenkiana in the Tianshan Mountains. Long-term daily climatic data (1957-2017) were derived from the Aksu Meteorological Station.

\subsection{Dendrochronological Study and Annual Carbon Sequestration Calculation}

Cores were brought back to the laboratory, air-dried, fixed, and polished with successively finer grades of sandpaper until annual rings could be distinguished easily [37]. Tree-ring widths were then measured with a precision of $0.001 \mathrm{~mm}$ by using a LINTAB system. The quality and accuracy of cross-dated tree-ring series were assessed using COFECHA software [37]. In order to accurately determine the growth characteristics of each age group of trees, standardization techniques were avoided, such as detrending, which removed age-related or non-climatic trends from tree-ring data that were commonly used for climate reconstructions [1]. Based on the tree-ring widths and the DBH at the 
time of coring, historic DBHs for each calendar year were computed backwards to the first tree-ring formed at DBH [1]. Considering that the measured DBH is the sum of the thicknesses of bark, phloem and xylem, we regard the difference between DBH and the sum of tree-ring width as the total bark and phloem diameter thickness, and then calculate annual bark and phloem growth thickness according to the proportion of annual tree-ring growth width to the sum of tree-ring width. Defining the year nearest to the phloem and bark as $n$, we have $D B H_{n}=D B H$. Accordingly, we define the next year nearest to the phloem and bark as $n-1$, and we have $D B H_{n-1}=D B H-2 \times r_{n}-\left(D B H-2 \times \sum_{n}^{i} r\right) \times \frac{r}{\sum_{n}^{i} r} \times 100 \%$. The nearest third year to the phloem and bark as $n-2$, and we have $D B H_{n-2}=$ $D B H-2 \times\left(r_{n}+r_{n-1}\right)-\left(D B H-2 \times \sum_{n}^{i} r\right) \times \frac{r_{n}+r_{n-1}}{\sum_{n}^{i} r} \times 100 \%$, etc. The year measured closest to the pith is $i$, and then we have $D B H_{i}=D B H-2 \times\left(r_{n}+r_{n-1}+\ldots+r_{i+1}\right)-$ $\left(D B H-2 \times \sum_{n}^{i} r\right) \times \frac{r_{n}+r_{n-1}+\cdots+r_{i+1}}{\sum_{n}^{i} r} \times 100 \%$, in which $n$ is the year closest to phloem and bark (2017 in this study), $i$ is the year that we can measure closest to the pith, $D B H-2 \times \sum_{n}^{i} r$ is the sum of phloem and bark, and $\frac{r_{n}}{\sum_{n}^{i} r} \times 100 \%$ is the percentage of tree-ring width of $n$th year in the sum of tree-ring width. For the cores that did not pass through the pith, the number of additional years to the pith was estimated by dividing the radius of curvature of the innermost ring boundary using the average width of the four innermost rings [38,39].

Zhang et al. grouped P. schrenkiana trees in Tianshan Mountains into the following three forest stand structure:(1) exploratory phase (trees without signs of damage, no or very little deadwood); (2) degeneration phase (weakened trees, little deadwood), and (3) stagnation phase (clearly damaged trees, increased deadwood). They selected 15 trees from each forest stand structure to estimate P. schrenkiana forest stand biomass by the mean sample tree method, the class mean sample tree method, the regression method, and the direct weighing method (cutting down trees in the field and immediately weighing the aboveground wood, bark, branches, and leaves) [26]. Then they suggested that the regression method based on $\mathrm{DBH}$ was the most convenient and appropriate method for estimating the aboveground biomass of P. schrenkiana forest in the Tianshan Mountains, and the fitting results of regression models could reach an accuracy of $91-99 \%$ of the field weighing measured results [26]. In this study, we used the following allometric equations based on DBH provided by Zhang et al. to assess annual biomass of P. schrenkiana forest [26]:

$$
\begin{array}{ccc}
\lg W_{\text {woody }}=2.53932 \lg D-1.21436 & E: 0.87 \% & r=0.9924 \\
\lg W_{\text {bark }}=2.33033 \lg D-1.83587 & E: 4.25 \% & r=0.9902 \\
\lg W_{\text {branches }}=3.00489 \lg D-2.60922 & E: 7.16 \% & r=0.9817 \\
\lg W_{\text {leaves }}=2.27792 \lg D-1.74823 & E: 7.73 \% & r=0.9660 \\
W=W_{\text {woody }}+W_{\text {bark }}+W_{\text {branches }}+W_{\text {leaves }}
\end{array}
$$

where $W$ is aboveground biomass; $W_{\text {woody }}$ is aboveground woody biomass; $W_{\text {bark }}$ is aboveground bark biomass; $W_{\text {branches }}$ is aboveground branch biomass; $W_{\text {leaves }}$ is aboveground leaf biomass; $D$ is diameter at breast height $(\mathrm{DBH}) ; E$ is regression relative error, and $r$ is correlation coefficient. The biomass values were multiplied by 0.5 to derive the tree's carbon stocks $[1,40]$. Then these values were transformed into annual carbon sequestration potential capacity in aboveground biomass as the difference between two consecutive years $[1,40]$.

Large-scale field forest inventories implemented by the Chinese government are mostly conducted once every 5 or 10 years, or even once in more than one decade. As the latest forest density and area data that we obtained were forest inventory data of the Xinjiang Forestry Department in 2016, and continuous annual forest density and area data were unavailable, we only estimated carbon storage of $P$. schrenkiana forest in the Tianshan 
Mountains in 2016. For the long time-series, however, we calculated the annual carbon sequestration potential capacity of $P$. schrenkiana in successive years.

\subsection{Classification and Regression Tree Model (CART Model) and Statistical Analyses}

In contrast to classic dendrochronological approaches, which frequently rely on correlation analysis, the classification and regression tree model (CART model) achieves the best predictions compared to logistic multiple regression, generalized linear models, and principal component regression models [1,40]. Furthermore, CART can incorporate response variables and predictor variables characterized by the absence of normality, as well as nonlinear relationships to the response [1,41]. CART yields decision trees by repeated binary splits at explicit threshold values of the respective predictor to increase homogeneity within, and heterogeneity between, groups. These thresholds generate a general prediction rule for carbon sequestration potential capacity, which can be interpreted as climatic drivers limiting the carbon sequestration potential capacity of P. schrenkiana. In view of these advantages, we utilized the CART model to elucidate the relationship between climatic variables and cross-dated chronology of annual carbon sequestration potential capacity in aboveground biomass of $P$. schrenkiana and attempted to quantify the contribution of each variable to corresponding carbon sequestration.

Long-term daily climatic data were derived from the Aksu Meteorological Station from the beginning of continuous instrumental data (1957-2017). The initial set of continuous and independent climate predictor variables comprised monthly temperature, precipitation, relative humidity, wind velocity, and sunshine duration means for each calendar year and the previous calendar year. All data were analyzed descriptively, with normality (ShapiroWilk test) and homogeneity of variance (Fligner test), prior to modeling. Correlations between climate variables and carbon sequestration potential capacity in aboveground biomass showed that both variables in the current year and the previous year might be associated with carbon sequestration potential capacity in aboveground biomass, which suggested that a lagged effect of climate on tree growth might exist. Accordingly, we divided the predictor variables into four main stages that affected tree growth: (1) growth year (previous October-current September); (2) previous growth year (previous Aprilcurrent March); (3) growing season (April-September), and (4) dormant season (previous October-current March). Considering the critical importance of temperature to plants, we divided temperature into mean temperature, maximum temperature, and minimum temperature. This procedure produced 28 independent climatic variables from seven indices, which were presented in Table 1. To avoid over-fitting, proper tree size was estimated by using the cross-validation error estimate. To calibrate the results of CART, Nash-Sutcliffe coefficient (NS), percent bias (PBIAS), and coefficient of determination $\left(R^{2}\right)$ were also used in the study.

The objective function for calibration is the Nash-Sutcliffe coefficient (NS) [42]:

$$
N S=1-\frac{\sum_{i=1}^{n}\left(Y_{i}^{o b s}-Y_{i}^{s i m}\right)^{2}}{\sum_{i=1}^{n}\left(Y_{i}^{\text {obs }}-Y_{\text {mean }}\right)^{2}}
$$

where $Y_{i}^{o b s}$ and $Y_{i}^{s i m}$ are the $i$ observed and simulated carbon sequestration, respectively; $Y_{\text {mean }}$ is the mean of observed data; $n$ is the number of observations; and NS indicates whether or not the simulation closely matches the observation. NS ranges between $-\infty$ and 1.0, with $N S=1$ meaning a perfect fit, i.e., the higher is the value of NS, the more accurate is the model [42].

To evaluate model performance, PBIAS and $R^{2}$ were also computed [42]:

$$
\text { PBIAS }=\frac{\sum_{i=1}^{n}\left(Y_{i}^{s i m}-Y_{i}^{o b s}\right)}{\sum_{i=1}^{n}\left(Y_{i}^{o b s}\right)}
$$


Table 1. Response and predictor variables used for modeling the relationship between carbon sequestration in aboveground biomass of P. schrenkiana and climatic changes.

\begin{tabular}{|c|c|c|}
\hline Model & Response Variables & Predictor Variables \\
\hline \multirow{13}{*}{$\begin{array}{l}\text { Classification and } \\
\text { regression tree model } \\
\text { (CART) }\end{array}$} & \multirow{13}{*}{$\begin{array}{l}\text { Mean annual carbon } \\
\text { sequestration potential } \\
\text { capacity of: } \\
\text {-P. schrenkiana in the } \\
\text { Tianshan Mountains }\end{array}$} & Climatic Parameters \\
\hline & & Temperature \\
\hline & & $\begin{array}{ll} & \text { average temperature in growing season }\left(\mathrm{T}_{\text {mean }} \mathrm{GS}\right) \\
- & \text { average temperature in dormant season }\left(\mathrm{T}_{\text {mean }} \mathrm{DS}\right) \\
- & \text { average temperature in growing year }\left(\mathrm{T}_{\text {mean }} \mathrm{GY}\right) \\
- & \text { average temperature in previous growing year }\left(\mathrm{T}_{\text {mean }} \mathrm{PGY}\right)\end{array}$ \\
\hline & & $\begin{array}{ll}- & \text { average minimum temperature in dormant season }\left(\mathrm{T}_{\min } \mathrm{GS}\right) \\
- & \text { average minimum temperature in dormant season }\left(\mathrm{T}_{\min } \mathrm{DS}\right) \\
- & \text { average minimum temperature in growing year }\left(\mathrm{T}_{\min } \mathrm{GY}\right) \\
- & \text { average minimum temperature in previous growing year }\left(\mathrm{T}_{\min } \mathrm{PGY}\right)\end{array}$ \\
\hline & & $\begin{array}{ll}- & \text { average maximum temperature in dormant season }\left(\mathrm{T}_{\max } \mathrm{GS}\right) \\
- & \text { average maximum temperature in dormant season }\left(\mathrm{T}_{\max } \mathrm{DS}\right) \\
- & \text { average maximum temperature in growing year }\left(\mathrm{T}_{\max } \mathrm{GY}\right) \\
- & \text { average maximum temperature in previous growing year }\left(\mathrm{T}_{\max } \mathrm{PGY}\right)\end{array}$ \\
\hline & & Precipitation \\
\hline & & $\begin{array}{ll}- & \text { total precipitation in growing season (PGS) } \\
- & \text { total precipitation in dormant season (PDS) } \\
- & \text { total precipitation in growing year (PGY) } \\
- & \text { total precipitation in previous growing year (PPGY) }\end{array}$ \\
\hline & & Wind velocity \\
\hline & & $\begin{array}{ll}- & \text { average wind velocity in growing season (WGS) } \\
- & \text { average wind velocity in dormant season (WDS) } \\
- & \text { average wind velocity in growing year (WGY) } \\
- & \text { average wind velocity in previous growing year (WPGY) }\end{array}$ \\
\hline & & Sunshine duration \\
\hline & & $\begin{array}{ll}- & \text { total sunshine duration in growing season (SGS) } \\
- & \text { total sunshine duration in dormant season (SDS) } \\
- & \text { total sunshine duration in growing year (SGY) } \\
- & \text { total sunshine duration in previous growing year (SPGY) }\end{array}$ \\
\hline & & Relative humidity \\
\hline & & $\begin{array}{ll}\text { - } & \text { mean relative humidity in growing season (RGS) } \\
\text { - } & \text { mean relative humidity in dormant season (RDS) } \\
\text { - } & \text { mean relative humidity in growing year (RGY) } \\
\text { - } & \text { mean relative humidity in previous growing year (RPGY) }\end{array}$ \\
\hline
\end{tabular}

PBIAS measures the average deviation of the simulated data from their observed counterparts. Positive values of PBIAS indicate an overestimation of the observation, while negative values indicate an underestimation. Generally, $|P B I A S|<10 \%$ indicates good modeling, and $R^{2}$ describes the degree of collinearity between simulated and measured data.

It is widely recognized that NS $>0.50,|P B I A S|<25 \%$ and $R^{2}>0.6$ are taken as the criteria of a satisfactory model, and model performance can be evaluated as excellent if NS $>0.75$ and $|P B I A S|<10 \%$ [42].

\section{Results}

\subsection{Mean Carbon Sequestration Potential Capacity Chronologies}

The time sequence of mean tree-ring width chronology of P. schrenkiana in the Tianshan Mountains was 1813-2017, which was determined by common periods of more than 10 cores (Figure 2A). Considering that the standard deviation values of average tree-ring 
width chronology in 1813-1850 were relatively large, we built the carbon sequestration potential capacity chronology post- 1850 (Figure 2B). Although the annual carbon sequestration potential capacity in aboveground biomass of P. schrenkiana in 1850-1880 decreased at a rate of $0.29 \mathrm{~kg} \mathrm{C} . \mathrm{y}^{-1}$, it exhibited an increasing tendency from 1881-2017 at a rate of $0.13 \mathrm{~kg} \mathrm{C} . \mathrm{y}^{-1}$ (Figure 3). During the 70 years from 1881-1950, the annual carbon sequestration potential capacity, i.e., an average value of $10.86 \mathrm{~kg} \mathrm{C.y}{ }^{-1}$, increased relatively slowly at a rate of $0.03 \mathrm{~kg} \mathrm{C.y^{-1 }}$. However, it increased rapidly from 1951-2017, with an average value of $20.11 \mathrm{~kg} \mathrm{C} . \mathrm{y}^{-1}$ and a rate of $0.21 \mathrm{~kg} \mathrm{C} . \mathrm{y}^{-1}$ (Figure 3). The increasing rate of annual carbon sequestration potential capacity in 1951-2017 was 4.25 times that in 1881-1950, and the average annual carbon sequestration potential capacity in 1951-2017 increased $85.22 \%$ compared to that in 1881-1950. These results suggested that the carbon sequestration potential capacity in aboveground biomass of $P$. schrenkiana in the Tianshan Mountains entered a period of rapid increase post-1950.

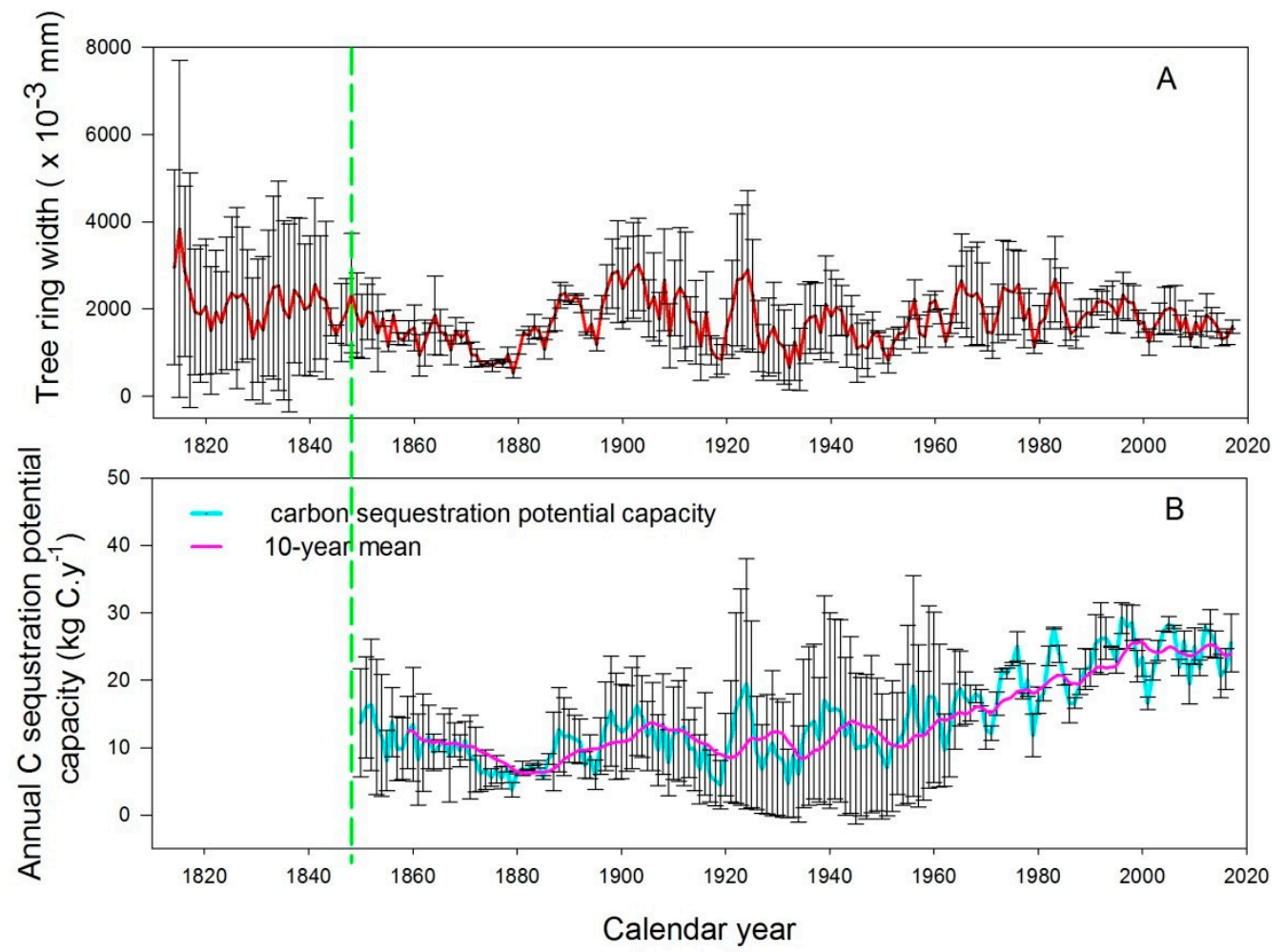

Figure 2. Tree-ring width chronology (A), and carbon sequestration potential capacity (B) in aboveground biomass of P. schrenkiana in the Tianshan Mountains. (C sequestration potential capacity: carbon sequestration potential capacity). 

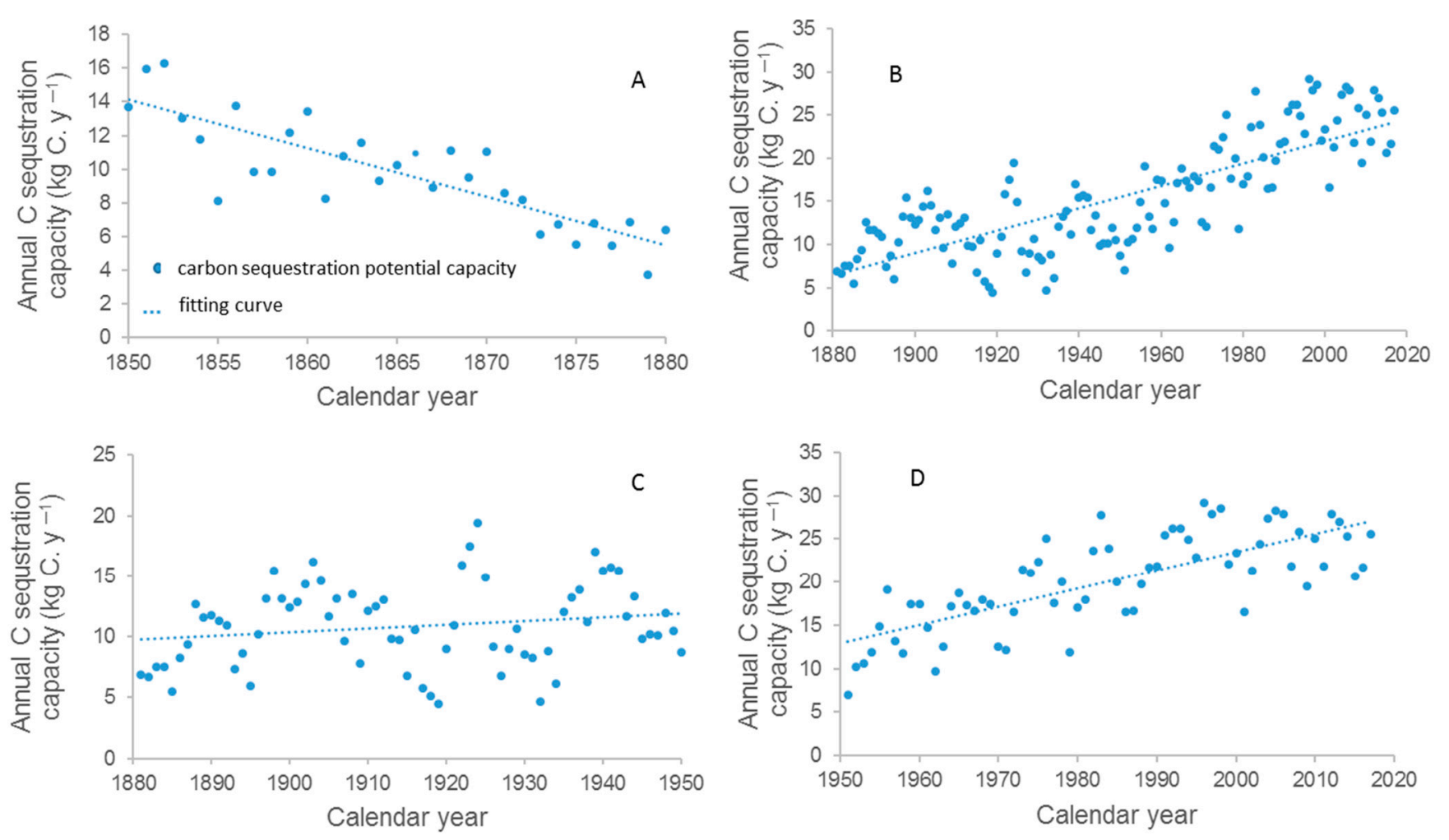

Figure 3. Change trends of carbon sequestration potential capacity in aboveground biomass of P. schrenkiana from different periods ((A) 1850-01880; (B) 1881-2017; (C) 1881-1950; (D) 1951-2017) in the Tianshan Mountains. (C sequestration potential: carbon sequestration potential capacity).

Combining forest density and area data from forest inventory of the Xinjiang Forestry Department in 2016 and the accumulated aboveground biomass of woody mass, bark, branches, and leaves that we estimated in 2016 in the study, the mean carbon density and total carbon storage of P. schrenkiana forest in the Tianshan Mountains were calculated (Table 2). The estimation results showed that the total carbon storage of aboveground trees of P. schrenkiana forest was $50.08 \mathrm{Tg}$ C in 2016.

Table 2. Aboveground biomass, carbon density, and carbon storage in P. schrenkiana forest in the Tianshan Mountains.

\begin{tabular}{|c|c|c|c|c|}
\hline Item & $\begin{array}{l}\text { Average Aboveground } \\
\text { Biomass per Tree (kg) }\end{array}$ & $\begin{array}{c}\text { Average Aboveground } \\
\text { Biomass per Hectare } \\
\left(\mathrm{t} \cdot \mathrm{h} \mathrm{a}^{-1}\right)\end{array}$ & $\begin{array}{c}\text { Mean Carbon } \\
\text { Density per Hectare } \\
\left(\mathrm{t} \cdot \mathrm{ha}^{-1}\right)\end{array}$ & $\begin{array}{l}\text { Total Carbon Storage of } \\
\text { P. schrenkiana Forest (Tg C) }\end{array}$ \\
\hline Woody & $178.09 \pm 17.42$ & $216.38 \pm 29.84$ & $108.19 \pm 9.02$ & $33.93 \pm 1.31$ \\
\hline Bark & $18.06 \pm 1.24$ & $21.94 \pm 1.86$ & $10.97 \pm 1.04$ & $3.44 \pm 0.25$ \\
\hline Branches & $48.85 \pm 8.13$ & $59.35 \pm 4.39$ & $29.67 \pm 2.98$ & $9.31 \pm 0.67$ \\
\hline Leaves & $17.83 \pm 1.01$ & $21.66 \pm 2.01$ & $10.83 \pm 0.76$ & $3.40 \pm 0.13$ \\
\hline Sum & $262.82 \pm 7.72$ & $319.33 \pm 13.59$ & $159.66 \pm 3.84$ & $50.08 \pm 0.53$ \\
\hline
\end{tabular}

\subsection{PotentialClimatic Causes of Carbon Sequestration Capacity Change}

Pearson correlations demonstrated that $T_{\text {mean }} G S, T_{\min } G S, T_{\max } G S, T_{\text {mean }} D S, T_{\min } D S$, $\mathrm{T}_{\text {mean }} \mathrm{GY}, \mathrm{T}_{\text {min }} \mathrm{GY}, \mathrm{T}_{\text {mean }}$ PGY, $\mathrm{T}_{\text {min }}$ PGY, SGS, SDS, WGS, WDS, WGY, WPGY, PDS, PGY, and PPGY were closely related to carbon sequestration in aboveground biomass of P. schrenkiana (Table 3). Notably, some climatic variables were linearly associated to carbon sequestration chronologies, whereas, no obvious linear relationships were found between the other factors and carbon sequestration chronologies. Collinearity (VIF values) between climatic variables was subsequently examined (Table 4). Multiple collinearity tests revealed that strong multi-collinearity existed between many climatic variables, which were characterized by tolerance value $<1$ and VIF value $>10$. These results implied that general regression models (e.g., linear models, logistic multiple regression, principal component regression, 
etc.) could not be conducted directly because collinearity between variables would easily cause model distortion. Therefore, we selected the CART model to further analyze the key climatic drivers affecting carbon sequestration capacity and quantify the importance of each predictor variable to carbon sequestration capacity in aboveground biomass of the P. schrenkiana in the Tianshan Mountains. CART model validation results demonstrated that the NS was 0.81 , which indicated that the model was reliable. Moreover, the $\mid$ PBIAS| of models was $<10 \%$, and $\mathrm{R}^{2}$ of the simulated and observed data from the model was 0.81 . In addition, resubstitution values of the model were 1.77 , and cross-validation values were 9.04. Based on these statistical findings, the CART model performance was shown to be excellent, and the simulations were reliable.

Table 3. Correlations between climatic variables and carbon sequestration capacity of $P$. schrenkiana in the Tianshan Mountains.

\begin{tabular}{|c|c|c|c|}
\hline Variables & $\begin{array}{c}\text { Carbon } \\
\text { Sequestration } \\
\text { Capacity }\end{array}$ & Variables & $\begin{array}{c}\text { Carbon } \\
\text { Sequestration } \\
\text { Capacity }\end{array}$ \\
\hline PGS & 0.2058 & PGY & 0.3170 * \\
\hline SGS & $0.3716^{* *}$ & SGY & 0.186 \\
\hline $\mathrm{T}_{\text {mean }} \mathrm{GS}$ & $0.3614^{* *}$ & $\mathrm{~T}_{\text {mean }} \mathrm{GY}$ & $0.4523^{* *}$ \\
\hline $\mathrm{T}_{\min } \mathrm{GS}$ & $0.4690^{* *}$ & $\mathrm{~T}_{\min } \mathrm{GY}$ & $0.5446^{* *}$ \\
\hline $\mathrm{T}_{\max } \mathrm{GS}$ & $0.3947^{* *}$ & $\mathrm{~T}_{\max } \mathrm{GY}$ & 0.2738 \\
\hline RGS & 0.006 & RGY & 0.1236 \\
\hline WGS & $-0.4467^{* *}$ & WGY & $-0.4060^{* *}$ \\
\hline PDS & $0.3541^{* *}$ & PPGY & $0.4213^{* *}$ \\
\hline SDS & $-0.2850 *$ & SPGY & 0.0432 \\
\hline $\mathrm{T}_{\text {mean }} \mathrm{DS}$ & $0.3704^{* *}$ & $\mathrm{~T}_{\text {mean }} \mathrm{PGY}$ & $0.3798^{* *}$ \\
\hline $\mathrm{T}_{\min } \mathrm{DS}$ & $0.4945^{* *}$ & $\mathrm{~T}_{\min } \mathrm{PGY}$ & $0.5177^{* *}$ \\
\hline $\mathrm{T}_{\max } \mathrm{DS}$ & 0.0104 & $\mathrm{~T}_{\max } \mathrm{PGY}$ & 0.1605 \\
\hline RDS & 0.148 & RPGY & 0.1433 \\
\hline WDS & $-0.3693^{* *}$ & WPGY & $-0.4577^{* *}$ \\
\hline
\end{tabular}

**: significant level at $0.01 ;{ }^{*}$ : significant level at 0.05 .

Table 4. Results of multiple collinearity test between climatic variables.

\begin{tabular}{cccccc}
\hline Variables & Tolerance & VIF & Variables & Tolerance & VIF \\
\hline PGS & 0.4968 & 2.0129 & $\mathrm{~T}_{\min } \mathrm{GY}$ & 0.0000 & $117,778.4100$ \\
PDS & 0.4265 & 2.3448 & $\mathrm{~T}_{\min } \mathrm{PGY}$ & 0.0070 & 143.6409 \\
PGY & 0.0000 & & $\mathrm{~T}_{\max } \mathrm{GS}$ & 0.0035 & 287.5557 \\
PPGY & 0.4071 & 2.4566 & $\mathrm{~T}_{\max } \mathrm{DS}$ & 0.0017 & 580.6444 \\
SDS & 0.0954 & 10.4862 & $\mathrm{~T}_{\max } \mathrm{GY}$ & 0.0011 & 921.6222 \\
SGS & 0.0000 & & $\mathrm{~T}_{\max } \mathrm{PGY}$ & 0.0122 & 81.9503 \\
$\mathrm{SGY}$ & 0.2545 & 3.9297 & RGS & 0.07962 & 12.5594 \\
SPGY & 0.1715 & 5.8301 & RDS & 0.0658 & 15.1959 \\
$\mathrm{~T}_{\text {mean }} \mathrm{GS}$ & 0.0131 & 76.2878 & RGY & 0.0000 & $438,094.9000$ \\
$\mathrm{~T}_{\text {mean }} \mathrm{DS}$ & 0.0043 & 234.0927 & RPGY & 0.0390 & 25.6147 \\
$\mathrm{~T}_{\text {mean }} \mathrm{GY}$ & 0.0000 & $32,371.0178$ & WGS & 0.0004 & 2709.2722 \\
$\mathrm{~T}_{\text {mean }} \mathrm{PGY}$ & 0.0038 & 264.9590 & WDS & 0.0007 & 1421.7260 \\
$\mathrm{~T}_{\text {min }} \mathrm{GS}$ & 0.0280 & 35.7219 & WGY & 0.0001 & 7033.4315 \\
$\mathrm{~T}_{\text {min }} \mathrm{DS}$ & 0.0112 & 89.6770 & WPGY & 0.0861 & 11.6160 \\
\hline
\end{tabular}

The nodes of the CART model can be interpreted as environmental thresholds of drivers that reduce variability in carbon sequestration capacity of the tree pool, such that the trees respond similarly to changing parameters in time [1]. The results of the CART model showed (Figure 4 ) that $\mathrm{T}_{\min } \mathrm{DS}, \mathrm{T}_{\min } \mathrm{GS}, \mathrm{SDS}, \mathrm{RGY}, \mathrm{WDS}$, and $\mathrm{T}_{\text {mean }} \mathrm{GS}$ constituted decisive climatic variables in carbon sequestration capacity in aboveground biomass of the P. schrenkiana, and $-5.92{ }^{\circ} \mathrm{C}$ of $\mathrm{T}_{\min }$ in the dormant season was the most decisive driver. Therefore, the most important climatic driver of carbon sequestration in aboveground biomass of the P. schrenkiana in the Tianshan Mountains was temperature. 


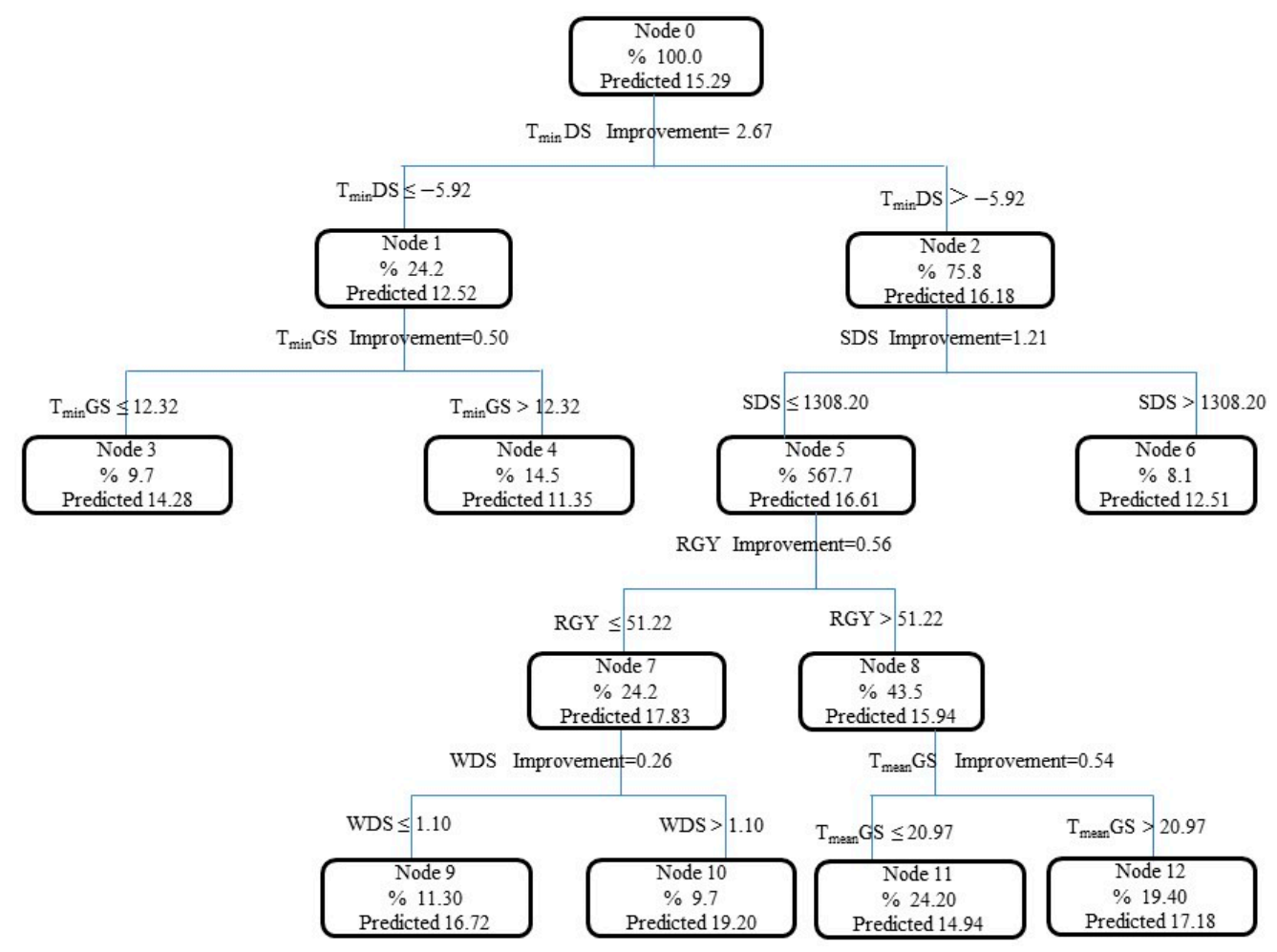

Figure 4. Climatic variables used for CART modeling carbon sequestration in ABM of P. schrenkiana in the Tianshan Mountains (CART: classification and regression tree model; ABM: above ground biomass).

Additionally, the change trend of global average annual temperature anomaly from 1880-2017 was highly consistent with annual carbon sequestration capacity in aboveground biomass of $P$. schrenkiana in the Tianshan Mountains (Figure 5, $r=0.912, p<0.01$ ). This further confirmed that temperature was the critical climatic factor affecting forest carbon sequestration.

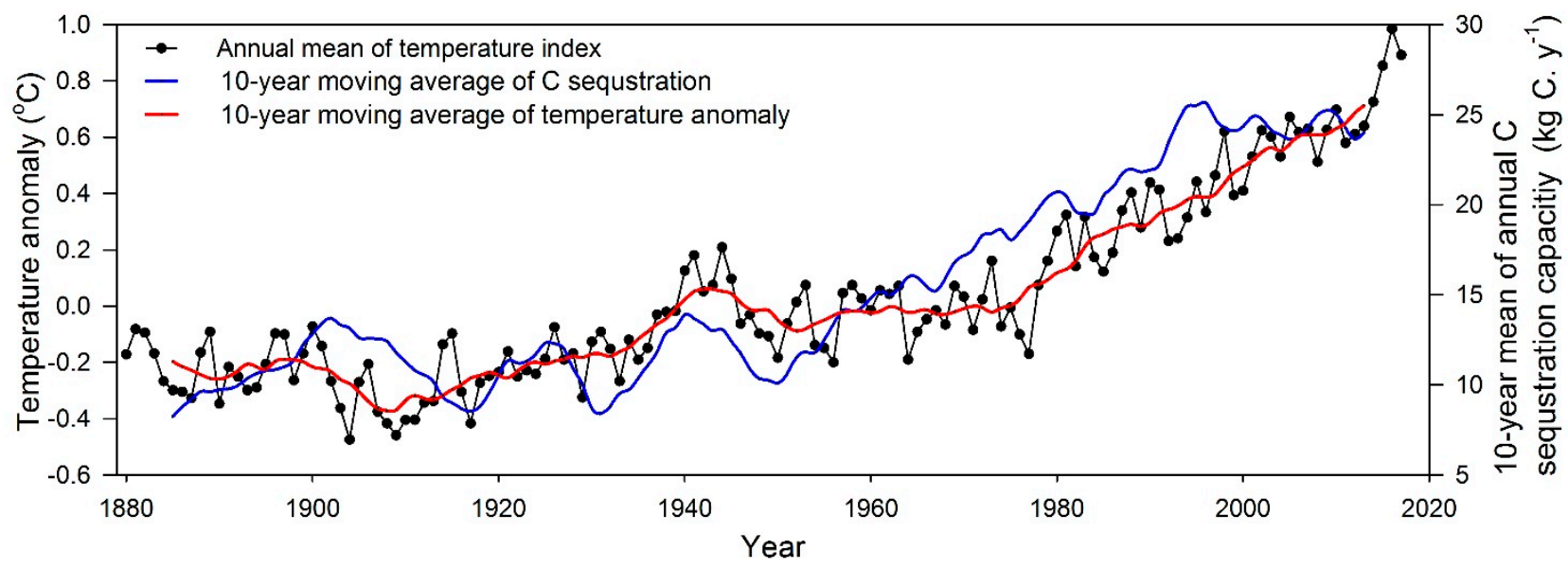

Figure 5. Relationship between global land-ocean temperature index and carbon sequestration capacity in aboveground biomass of P. schrenkiana in the Tianshan Mountains (global annual average temperature anomaly obtained from NASA GISS).

\subsection{Contribution of Temperature to Carbon Sequestration}

According to the normalized importance values, the top-10 climatic drivers affecting carbon sequestration capacity in aboveground biomass of $P$. Schrenkiana in the Tianshan Mountains were as follows, in decreasing order of importance: $T_{\min } G Y, T_{\min } D S, T_{\min } P G Y$, 
$\mathrm{T}_{\text {mean }} \mathrm{DS}, \mathrm{T}_{\text {mean }} \mathrm{GY}, \mathrm{T}_{\text {mean }} \mathrm{PGY}, \mathrm{SDS}, \mathrm{T}_{\min } \mathrm{GS}, \mathrm{RGY}$, and WDS, and their normalized importance was $100 \%, 95.01 \%, 94.91 \%, 86.74 \%, 83.37 \%, 77.47 \%, 74.96 \%, 67.91 \%, 61.78 \%$ and $61.12 \%$, respectively (Figure 6 ). These 10 drivers comprised $58.59 \%$ of the sum of the importance of all 28 climatic factors. In addition, temperature, including four $\mathrm{T}_{\min }$ indicators and three $\mathrm{T}_{\text {mean }}$ indicators, accounted for $44.16 \%$ of the sum of importance values of 28 climatic factors and $75.37 \%$ of the sum of importance values of 10 drivers. Moreover, $\mathrm{T}_{\min }$ and $\mathrm{T}_{\text {mean }}$ indicators constituted $26.10 \%$ and $18.06 \%$ of the sum of importance values of 28 climatic factors, respectively, and comprised $44.55 \%$ and $30.82 \%$ of the sum of importance values of 10 main drivers, respectively. SDS constituted $5.47 \%$ of the sum of importance values of 28 climatic factors and $9.33 \%$ of the sum of importance values of 10 drivers. RGY comprised $4.51 \%$ of the sum of importance values of 28 climatic factors and $7.69 \%$ of the sum of importance values of 10 drivers. Furthermore, WDS accounted for $4.46 \%$ of the sum of importance values of 28 climatic factors and $7.61 \%$ of the sum of importance values of 10 drivers. These results indicated that $\mathrm{T}_{\min }$, i.e., minimum temperature, made the greatest contribution to the change of carbon sequestration capacity in aboveground biomass of P. schrenkiana in the Tianshan Mountains. It was also found that the second-most important climatic factor affecting carbon sequestration capacity was $T_{\text {mean }}$, i.e., mean temperature.

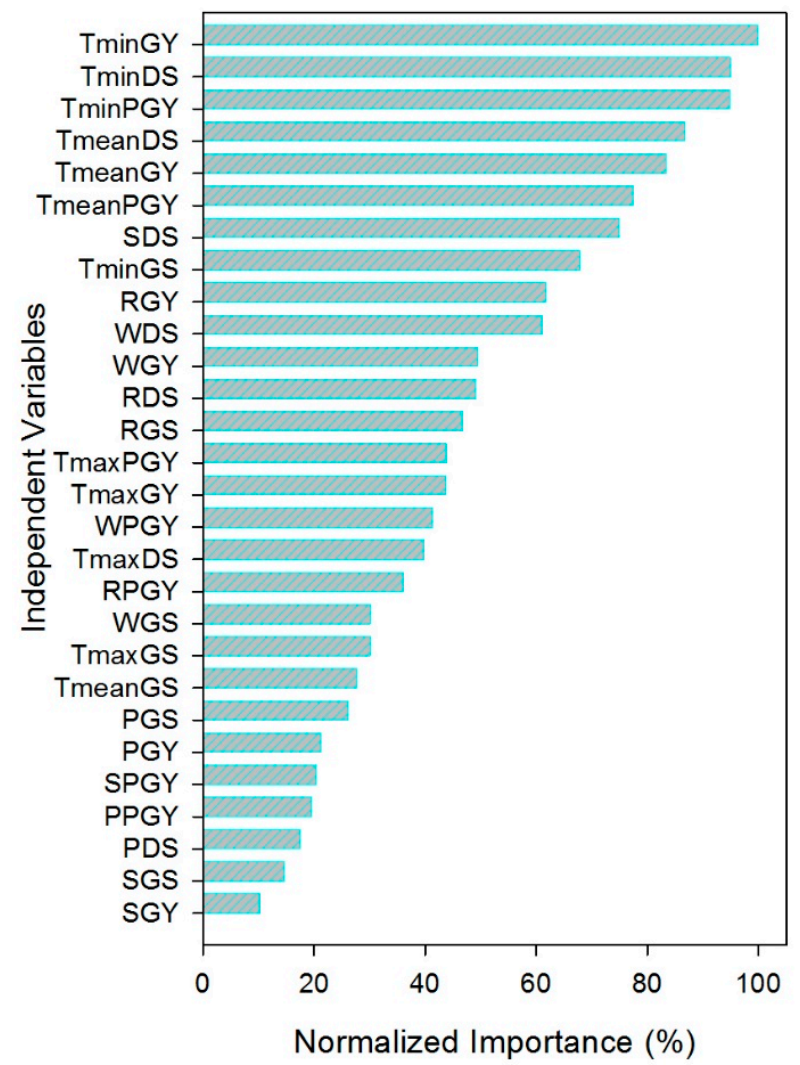

Figure 6. Normalized importance of climatic variables affecting carbon sequestration in ABM of P. schrenkiana in the Tianshan Mountains.

\section{Discussion}

Forest carbon sequestration in mountainous regions could provide crucial data for understanding the role of the carbon cycle in regional and global climate changes [43]. Carbon sequestration capacity has usually been investigated based on direct field measurements [23,44-47] or process-based terrestrial biosphere models [48-51]. In the current study, however, existing forest carbon sequestration of the Tianshan Mountains was estimated using data from national forest inventory or direct field measurements $[22,23,29,52,53]$. Although substantial work has already been performed, it remains challenging to understand and assess long-term and continuous carbon sequestration capacity because national or 
local forest inventory requires abundant human and material resources. As a consequence, large-scale field forest biomass surveys are mostly conducted once in 10 years or more, which makes field survey data coverage time short and intermittent and precludes the availability of very long-term (tens or hundreds of years) continuous annual data. Furthermore, popular remote-sensing interpretation can only be traced back to the 1970s. Constrained to the input of limited field survey and interpretation data, the carbon sequestration results simulated by different models are markedly dissimilar. For instance, Guo et al. estimated that total carbon storage in Xinjiang forests was $117.8 \mathrm{Tg}$ C in 2000 [54]; whereas Fang and Chen estimated that total carbon storage in Xinjiang forests was 73.53 Tg C in 2000 [46]. Therefore, determination of how to accurately and easily calculate long-term and continuous carbon sequestration capacity series of forests is a critical issue for carbon cycle evaluation. In this study, we used tree-ring width and DBH to evaluate long-term and continuous carbon sequestration capacity of P. schrenkiana in the Tianshan Mountains. The total carbon storage of P. schrenkiana forest in the Tianshan Mountains was $50.08 \mathrm{Tg} C$ in 2016 based on the method, which was in close accordance with that (53.14 Tg C in 2015) calculated by using direct field investigation data $[29,30]$. This proved that tree-ring width could be used as an effective estimator for evaluating long-term and continuous forest carbon sequestration and carbon storage if the tree-ring samples were obtained along different altitudes and different ages of the forest zone, where the trees could represent the growth trend of the forests. Indeed, this method was more convenient, time-saving, and economical than field inventory, and it also compensated for the short time-series of remote-sensing image interpretation.

The annual carbon sequestration potential capacity of P. schrenkiana in 1850-2017 in the Tianshan Mountains exhibited an increasing trend, especially in 1951-2017, which increased $85.22 \%$ compared to carbon sequestration potential capacity in 1881-1950. P. schrenkiana was mainly distributed in the middle and subalpine area of the Tianshan Mountains, where there was little human access and climate change would be the main factor affecting tree growth and development in mountains [33]. The effect of warming on forest carbon sequestration has long been a controversial topic. Studies have demonstrated that warming positively affects carbon sequestration capacity in forests [9,13-15,55]. However, Lim et al. suggested that two decades of soil warming did not significantly increase aboveground biomass accumulation and carbon sequestration in boreal Picea abies forest of Sweden [18]. Moreover, Yao et al. reported that warming was conducive to biomass and carbon accumulation in Picea abies and Betula populus, but such warming was unfavorable for those aspects in subtropical broadleaf forests in China [56]. Therefore, forest carbon sequestration response to warming depends on regional conditions and plant species. In the present study, Pearson analysis showed that temperature anomaly in 1880-2017 was significantly positively related to carbon sequestration capacity in aboveground biomass of P. schrenkiana in the Tianshan Mountains. CART also indicated that temperature, especially minimum temperature, was the most important climatic driver for carbon sequestration in aboveground biomass of P. schrenkiana. This is because temperature (1957-2017) explained more than approximately $75 \%$ of the long-term variation of carbon sequestration capacity between 10 climatic drivers, and minimum temperature explained approximately $44 \%$ of that amount. Therefore, warming was the key factor contributing to increased carbon sequestration potential capacity of P. schrenkiana in the Tianshan Mountains, which is also in accordance with Su et al.'s simulated results using models that showed that future warming would increase forest productivity by approximately $18.6 \%$ [22].

Air temperature in the arid region of northwestern China exhibited a significant increase, with a rate of $0.33-0.39{ }^{\circ} \mathrm{C} /$ decade during 1960-2010 [57,58]. Moreover, an investigation reported that the temperature rise in northwestern China showed a seasonal pattern: the rate of temperature increase in spring and summer was relatively low, varying within $0.22-0.32{ }^{\circ} \mathrm{C} /$ decade; whereas, the winter temperature rose much more rapidly, at a rate of $0.56-0.61{ }^{\circ} \mathrm{C} /$ decade [59]. Similarly, annual mean temperature in 1957-2017 in the study area exhibited an increase with a rate of $0.38{ }^{\circ} \mathrm{C} /$ decade, in which mean summer 
temperature varied with a rate of $0.25^{\circ} \mathrm{C} /$ decade, while mean winter temperature varied with a rate of $0.43{ }^{\circ} \mathrm{C} /$ decade (Figure 7). It was proven that the contribution of rising temperature in winter to warming played the most crucial role [59]. High temperature would usually inhibit plant growth or damage plants because it might cause an imbalance of plant cell metabolism, excessive accumulation of free radicals, or other abnormal physiological metabolism or molecular expression [60-62]. However, the maximum temperature in the study area did not obviously increase from 1957-2017; instead, the increase of minimum temperature was more significant than the mean and maximum temperature (Figure 7). This indicates that warming in the study area was also largely resultant from rising minimum temperature. Warming of minimum temperature, especially the increase in winter, would be beneficial to promote early germination of trees and delay dormancy of plants, thus extending the length of the growth periods of trees [22]. It may also enhance photosynthesis and the nutrient-availability of trees, which would finally increase NPP and carbon sequestration capacity of forests. As a result, carbon sequestration of $P$. schrenkiana forest in the Tianshan Mountains would markedly increase if warming in the future is similar to the change trends of the past few decades.
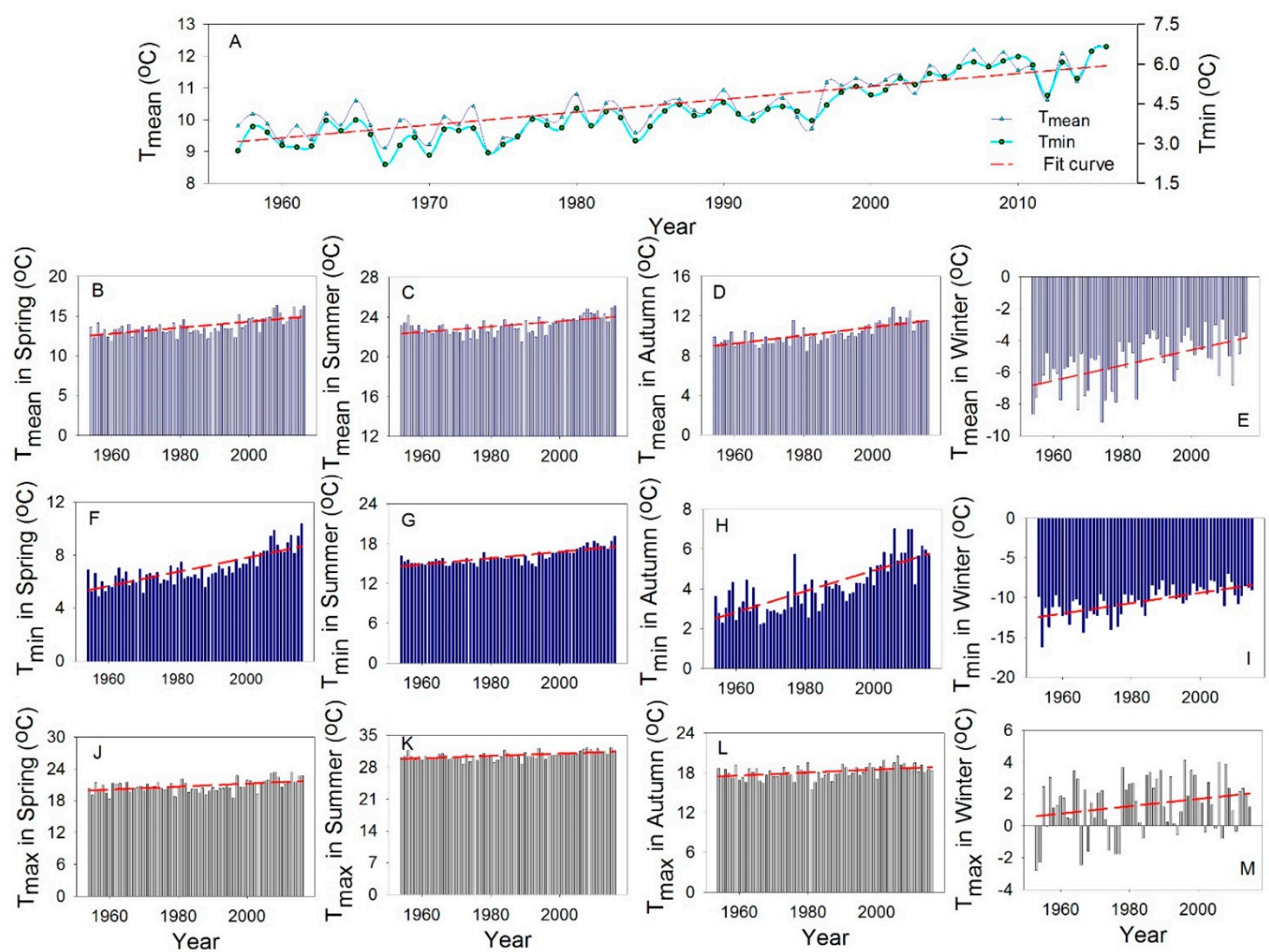

Figure 7. Changes of annual mean and minimum temperature (A), and mean (B-E), minimum (F-I), maximum (J-M) temperature in seasons from 1957-2017 in the study area.

\section{Conclusions}

This study was conducted to calculate the carbon sequestration potential capacity of P. schrenkiana in the Tianshan Mountains from 1850-2017 using dendrochronology, and analyze its responses to climate variables using CART model. Through the analyses, the following conclusions were reached: 
(1) Tree-ring width of P. schrenkiana could be utilized as a useful and effective estimator of productivity, carbon sequestration capacity, and carbon storage of $P$. schrenkiana forest in the Tianshan Mountains if the tree-ring samples were obtained along different altitudes and different ages of the forests.

(2) Temperature, especially minimum temperature, was the key climatic driver affecting carbon sequestration potential capacity changes in aboveground biomass of P. schrenkiana in the Tianshan Mountains, as shown by CART, and which positively contributed more than $75 \%$ of the variation of carbon sequestration.

(3) If the temperature in winter, especially the minimum temperature, exhibits a continuous rise in the future as it has in the past decades, the carbon sequestration potential capacity of $P$. schrenkiana forest in the Tianshan Mountains would increase significantly.

The findings of this study provide an effective and useful method to reconstruct historical carbon sequestration potential capacity or carbon storage in aboveground biomass of forests. Of course, our conclusions are only based on Tianshan Mountains using dendrochronology and CART model. It will be more helpful if more researchers use the methods or improved models to analyze and verify the conclusions of forests in the area or other areas, which is beneficial to predict and evaluate future change trends in aboveground carbon storage and carbon cycles of forest ecosystems.

Author Contributions: Conceptualization, H.Z.; writing—original draft preparation, Y.C. (Yaning Chen), C.Z., Y.C. (Yapeng Chen) and W.L.; review and editing, Y.Y. and S.C.; made the maps. All authors have read and agreed to the published version of the manuscript.

Funding: This research was funded by the Science and Technology Planning Project of Xinjiang Production and Construction Corps (Grant number 2020JS016), the National Natural Science Foundation of China (grant number U1703101), and the Natural Science Foundation of Xinjiang Province, China (Grant number 2017D01A79).

Data Availability Statement: The data can be obtained by contacting the author by email.

Acknowledgments: We thank Qifei Zhang and Zhenhua Xia in Xinjiang Institute of Ecology and Geography, Chinese Academy of Sciences, who gave us a lot of help in the field investigation and tree-ring collection. We also thank Weili Duan in Xinjiang Institute of Ecology and Geography, Chinese Academy of Sciences for reviewing the manuscript.

Conflicts of Interest: The authors declare that they have no known competing financial interests or personal relationships that could have appeared to influence the work reported in this paper.

\section{References}

1. Rieger, I.; Kowarik, I.; Cherubini, P.; Cierjacks, A. A novel dendrochronological approach reveals drivers of carbon sequestration in tree species of riparian forests across spatiotemporal scales. Sci. Total Environ. 2017, 574, 1261-1275. [CrossRef]

2. Read, D.J.; Beerling, D.J.; Cannell, M.; Cox, P.; Curran, P.; Grace, J.; Ineson, P.; Jarvis, P.; Malhi, Y.; Powlson, D.; et al. The Role of Land Carbon Sinks in Mitigating Global Climate Change; Policy Document; The Royal Society: London, UK, 2001.

3. Quéré, C.L.E.; Andrew, R.M.; Canadell, J.G.; Moriarty, R. Global Carbon Budget 2016. Earth Syst. Sci. Data 2016, 7, 521-610. [CrossRef]

4. Liu, Y.C.; Gao, X.L.; Fu, C.; Yu, G.R.; Liu, Z.Y. Estimation of carbon sequestration potential of forest biomass in China based on National Forest Resources Inventory. Acta Ecol. Sin. 2019, 39, 4002-4010.

5. Grassi, G.; House, J.; Dentener, F.; Federici, S.; Elzen, M.D.; Penman, J. The key role of forests in meeting climate targets requires science for credible mitigation. Nat. Clim. Chang. 2017, 7, 220-226. [CrossRef]

6. IPCC. Summary for policy makers. In Climate Change 2007: The Physical Science Basis. Contribution of Working Group I to the Fourth Assessment Report of the Intergovernmental Panel on Climate Change; Cambridge University Press: New York, NY, USA; Cambridge, UK, 2007.

7. Chen, J.; Yang, H. Advances and frontiers in global forest and harvested wood products carbon science. J. Nanjing For. Univ. (Nat. Sci. Ed.) 2018, 42, 1-8, (In Chinese with English Abstract).

8. Choat, B.; Brodribb, T.J.; Brodersen, C.R.; Duursma, R.A.; López, R.; Medlyn, B.E. Triggers of tree mortality under drought. Nature 2018, 558, 531-539. [CrossRef]

9. Clark, J.S.; Bell, D.M.; Hersh, M.H.; Nichols, L. Climate change vulnerability of forest biodiversity: Climate and competition tracking of demographic rates. Glob. Chang. Biol. 2011, 17, 1834-1849. [CrossRef] 
10. Savage, K.E.; Parton, W.J.; Davidson, E.A.; Trumbore, S.E.; Frey, S.D. Long-term changes in forest carbon under temperature and nitrogen amendments in a temperate northern hardwood forest. Glob. Chang. Biol. 2013, 19, 2389-2400. [CrossRef]

11. Melillo, J.M.; Steudler, P.A.; Aber, J.D.; Newkirk, K.; Lux, H.; Bowles, F.P.; Catricala, C.; Magill, A.; Ahrens, T.; Morrisseau, S. Soil warming and carbon-cycle feedbacks to the climate system. Science 2002, 298, 2173-2176. [CrossRef]

12. Goulden, M.L.; Wofsy, S.C.; Harden, J.W.; Trumbore, S.E.; Crill, P.M.; Gower, P.M.; Fries, S.T.; Daube, B.C.; Fan, S.M.; Sutton, D.J.; et al. Sensitivity of boreal forest carbon balance to soil thaw. Science 1998, 279, 214-217. [CrossRef]

13. Melillo, M.J.; Butler, S.; Johnson, J.; Mohan, J.; Steudler, P.; Lux, H.; Burrows, E.; Bowles, F.; Smith, R.; Scott, L.; et al. Soil warming, carbon-nitrogen interactions, and forest carbon budgets. Proc. Natl. Acad. Sci. USA 2011, 108, 9508-9512. [CrossRef]

14. Strömgren, M.; Linder, S. Effects of nutrition and soil warming on stem wood production in a boreal Norway spruce stand. Glob. Chang. Biol. 2002, 8, 1194-1204. [CrossRef]

15. Jarvis, P.G.; Linder, S. Constraints to growth of boreal forests. Nature 2000, 405, 904-905. [CrossRef] [PubMed]

16. Sutfin, N.A.; Wohl, E.E.; Dwire, K.A. Banking carbon: A review of organic carbon storage and physical factors influencing retention in floodplains and riparian ecosystems. Earth Surf. Process. Land 2016, 41, 38-60. [CrossRef]

17. Pichancourt, J.; Firn, J.; Chadès, I.; Martin, T.G. Growing biodiverse carbon-rich forests. Glob. Chang. Biol. 2014, 20, 382-393. [CrossRef] [PubMed]

18. Lim, H.; Oren, R.; Näholm, T.; Strögren, M.; Lundmark, T.; Grip, H.; Linder, S. Boreal forest biomass accumulation is not increased by two decades of soil warming. Nat. Clim. Chang. 2019, 9, 49-52. [CrossRef]

19. Rieger, I.; Kowarik, I.; Cierjacks, A. Drivers of carbon sequestration by biomass compartment of riparian forests. Ecosphere 2015, 6, 185. [CrossRef]

20. Berner, L.T.; Beck, P.S.A.; Bunn, A.G.; Goetz, S.J.; Beck, P.S.A. Plant response to climate change along the forest-tundra ecotone in north eastern Siberia. Glob. Chang. Biol. 2013, 19, 3449-3462.

21. Stegen, J.C.; Swenson, N.G.; Enquist, B.J.; White, E.P.; Phillips, O.L.; Jørgensen, P.M.; Weiser, M.D.; Monteagudo, M.A.; Nez, V.P. Variation I nabove-ground forest biomass across broad climatic gradients. Glob. Ecol. Biogeogr. 2011, 20, 744-754. [CrossRef]

22. Su, H.; Sang, W.; Wang, Y.; Ma, K. Simulating Picea schrenkiana forest productivity under climatic changes and atmospheric $\mathrm{CO}_{2}$ increase in Tianshan Mountains, Xinjiang Autonomous Region, China. For. Ecol. Manag. 2007, 246, 273-284. [CrossRef]

23. Ni, J. Forest productivity of the Altay and Tianshan Mountains in the dryland, northwestern China. For. Ecol. Manag. 2004, 202, 13-22. [CrossRef]

24. Wang, T.; Liang, Y.; Ren, H.; Yu, D.; Ni, J.; Ma, K. Age structure of Picea schrenkiana forest along an altitudinal gradient in the central Tianshan Mountains, northwestern China. For. Ecol. Manag. 2004, 196, 267-274. [CrossRef]

25. Wang, Y.; Zhao, S. A study on biomass and net productivity of Picea schrenkiana var. tianshanica forest. Chin. J. Appl. Ecol. 1999, 10, 389-391, (In Chinese with English Abstract).

26. Zhang, Y.S.; Wang, X.L.; Zhou, L.S. A preliminary study on the biomass determination of Picea schrenkiana forest. J. Xinjiang Agric. Univ. 1980, 3, 19-25, (In Chinese with English Abstract).

27. Qiu, L.; Zheng, J.H.; Wang, L.; Xuan, J.W.; Gao, Y.Q.; Luo, L. Spatiotemporal variation in the carbon sequestration rate of Larixsibirica in Xinjiang. Acta Ecol. 2018, 38, 6953-6963.

28. Sun, X.J.; Chang, S.L.; Zhang, Y.T.; Li, J.M. The variations in plant functional traits and forest carbon content with altitudinal gradients in the Tianshan Mountains. Ecol. Sin. 2018, 38, 4994-5005.

29. Xu, W.Q.; Yang, L.; Chen, X.; Gao, Y.Q.; Wang, L. Carbon storage, spatial distribution and the influence factors in Tianshan forests. Chin. J. Plant Ecol. 2016, 40, 364-373.

30. Zheng, S.L. Research on Biomass, Carbon Storage and Spatial Distribution of Picea schrenkiana and Larixsibirica in Xinjiang Tianshan and Altay Mountains. Master's Thesis, Xinjiang University, Ürümqi, China, 2016.

31. Wu, C.; Xu, G.; Chen, T.; Liu, X.; Zhang, Y.; An, W.; Wang, W.; Fang, Z.; Yu, S. Age-dependent tree-ring growth responses of Schrenk spruce (Picea schrenkiana) to climate-A case study in the Tianshan Mountain. Dendrochronologia 2013, 31, 318-326. [CrossRef]

32. Yu, S.; Yuan, Y.; Wei, W.; Chen, F.; Zhang, T.; Shang, H.; Zhang, R.; Qing, L. A 352-year record of summer temperature reconstruction in the western Tianshan Mountains, China, as deduced from tree-ring density. Quat. Res. 2013, 80, 158-166. [CrossRef]

33. Chen, F.; Shang, H.; Yuan, Y. Dry/wet variations in the eastern Tien Shan (China) since AD1725 based on Schrenk spruce (Picea schrenkiana Fisch. et Mey) tree rings. Dendrochronologia 2016, 40, 110-116. [CrossRef]

34. Ding, Y.; Zang, R.; Huang, J.; Xu, Y.; Lu, X.; Guo, Z.; Ren, W. Intraspecific trait variation and neighborhood competition drive community dynamics in an old-growth spruce forest in northwest China. Sci. Total Environ. 2019, 678, 525-532. [CrossRef] [PubMed]

35. Zhou, H.; Chen, Y.; Zhu, C.; Li, Z.; Fu, A. Climate change may accelerate the decline of desert riparian forest in the lower Tarim River, Northwestern China: Evidence from tree-rings of Populus euphratica. Ecol. Indic. 2020, 111, 105997. [CrossRef]

36. Brienen, R.J.W.; Gloor, E.; Zuidema, P.A. Detecting evidence for $\mathrm{CO}_{2}$ fertilization from tree ring studies: The potential role of sampling biases. Glob. Biogeochem. Cycles 2012, 26, GB1025. [CrossRef]

37. Zhou, H.; Chen, Y.; Hao, X.; Zhao, Y.; Fang, G.; Yang, Y. Tree rings: A key ecological indicator for reconstruction of groundwater depth in the lower Tarim River, Northwest China. Ecohydrology 2019. [CrossRef] 
38. Friedman, M.J.; Stricker, A.C.; Csank, Z.A.; Zhou, H. Effects of age and environment on stable carbon isotope ratios in tree rings of riparian Populus. Palaeogeogr. Palaeoclimatol. Palaeoecol. 2019, 524, 25-32. [CrossRef]

39. Meko, D.M.; Friedman, J.M.; Touchan, R.; Edmondson, J.R.; Griffin, E.R.; Scott, J.A. Alternative standardization approaches to improving streamflow reconstructions with ring-width indices of riparian trees. Holocene 2015, 25, 1093-1101. [CrossRef]

40. Giese, L.A.; Aust, W.M.; Kolka, R.K.; Trettin, C.C. Biomass and carbon pools of disturbed riparian forests. For. Ecol. Manag. 2003, 180, 493-508. [CrossRef]

41. De'ath, G.; Fabricius, K. Classification and regression trees: A powerful yet simple technique for ecological data analysis. Ecology 2000, 81, 3178-3192. [CrossRef]

42. Fang, G.; Yang, J.; Chen, Y.; Xu, C.; De Maeyer, P. Contribution of meteorological input in calibrating a distributed hydrologic model in a watershed in the Tianshan Mountains, China. Environ. Earth Sci. 2015, 74, 2413-2424. [CrossRef]

43. Dixon, R.K.; Brown, S.; Houghton, R.A.; Solomon, A.M.; Trexler, M.C.; Wisniewski, J. Carbon pools and flux of global forest ecosystems. Science 1994, 263, 185-190. [CrossRef]

44. Nabuurs, G.J.; Schelhaas, M.J. Spatial distribution of whole tree carbon stocks and fluxes across the forest of Europe: Where are the options for bio-energy. Biomass Bioenergy 2003, 24, 311-320. [CrossRef]

45. Goodale, C.L.; Apps, M.J.; Birdsey, R.A.; Field, C.B.; Heath, L.S.; Houghton, R.A.; Jenkins, J.C.; Kohlmaier, G.H.; Kurz, W.; Liu, S.R.; et al. Forest carbon sinks in the Northern Hemisphere. Ecol. Appl. 2002, 12, 891-899. [CrossRef]

46. Fang, J.Y.; Chen, A.P. Dynamic forest biomass carbon pools in China and their significance. Acta Bot. Sin. 2001, 43, 967-973, (In Chinese with English Abstract).

47. Jenkins, J.C.; Birdsey, R.A.; Pan, Y. Biomass and NPP estimation for the mid-Atlantic region (USA) using plot-level forest inventory data. Ecol. Appl. 2001, 11, 1174-1193. [CrossRef]

48. Lunt, H.P.; Fyfe, M.R.; Tappin, D.A. Role of recent climate change on carbon sequestration in peatland systems. Sci. Total Environ. 2019, 667, 348-358. [CrossRef] [PubMed]

49. Cramer, W.; Bondeau, A.; Woodward, F.I.; Prentice, I.C.; Betts, R.A.; Brovkin, V.; Cox, P.M.; Fisher, V.; Foley, J.A.; Friend, A.D.; et al. Global response of terrestrial ecosystem structure and function to $\mathrm{CO}_{2}$ and climate change: Results from six dynamic global vegetation models. Glob. Chang. Biol. 2001, 7, 357-373. [CrossRef]

50. Cao, M.K.; Woodward, F.I. Net primary and ecosystem production and carbon stocks of terrestrial ecosystems and their responses to climate change. Glob. Chang. Biol. 1998, 4, 185-198. [CrossRef]

51. Melillo, J.M.; McGuire, A.D.; Kicklighter, D.W.; Moore, B., III; Vorosmarty, C.J.; Scholss, A.L. Global climate change and terrestrial net primary production. Nature 1993, 363, 234-240. [CrossRef]

52. Zhou, G.S.; Wang, Y.H.; Jiang, Y.L.; Yang, Z.Y. Estimating biomass and net primary production from forest inventory data: A case study of China's Larix forests. For. Ecol. Manag. 2002, 169, 149-157. [CrossRef]

53. Wang, Y.; Zhao, S. Productivity pattern of Picea schrenkiana var. tianshanica forest. Acta Phytoecol. Sin. 2000, 24, 186-190, (In Chinese with English Abstract).

54. Guo, Z.D.; Hu, H.F.; Li, P.; Li, N.Y.; Fang, J.Y. Spatio-temporal changes in biomass carbon sinks in China's forests from 1977 to 2008. Sci. China Life Sci. 2013, 56, 661-671. [CrossRef]

55. Li, Y.; Bao, W.; Bongers, F.; Chen, B.; Chen, G.; Guo, K.; Jiang, M.; Lai, J.; Lin, D.; Liu, C.; et al. Drivers of tree carbon storage in subtropical forests. Sci. Total Environ. 2019, 654, 684-693. [CrossRef] [PubMed]

56. Yao, Y.; Piao, S.; Wang, T. Future biomass carbon sequestration capacity of Chinese forests. Sci. Bull. 2018, 63, 1108-1117. [CrossRef]

57. Zhang, Q.; Li, J.F.; Chen, Y.D.; Chen, X.H. Observed changes of temperature extremes during 1960-2005 in China: Natural or human-induced variations? Theor. Appl. Climatol. 2011, 106, 417-431. [CrossRef]

58. Wang, J.S.; Fei, X.L.; Wei, F. Further study of temperature change in northwest China in recent 50 years. J. Desert Res. 2008, 28, 724-732, (In Chinese with English Abstract).

59. Li, B.; Chen, Y.; Shi, X. Why does the temperature rise faster in the arid region of northwest China? J. Geophys. Res. Atmos. 2012, 117. [CrossRef]

60. Lin, J.; Zhu, Z. Plant responses to high temperature: A view from pre-mRNA alternative splicing. Plant Mol. Biol. 2021. [CrossRef] [PubMed]

61. Liu, X.Z.; Huang, B.R. Heat stress injury in relation to membrane lipid peroxidation in creeping bentgrass. Crop Sci. 2000, 40, 503-510. [CrossRef]

62. Wahid, A.; Gelani, S.; Ashraf, M.; Foolad, M. Heat tolerance in plants: An overview. Environ. Exp. 2007, 61, 199-223. [CrossRef] 